\title{
Endoscopic sphincterotomy in the young patient: is there cause for concern?
}

Laparoscopic cholecystectomy has become the preferred method for gall bladder removal with a significant impact on the management of common bile duct stones. In the recent past, patients undergoing open cholecystectomy would have undergone routine or selective intraoperative cholangiography, and if choledocholithiasis was found, this would have usually been managed by common bile duct exploration. Although there is an expanding array of laparoscopic procedures for removing common bile duct stones during laparoscopic cholecystectomy, they are technically challenging and not yet practised widely. ${ }^{12}$ The desire to avoid open surgery has increased the demand for management of bile duct stones by endoscopic retrograde cholangiopancreatography (ERCP). Endoscopic sphincterotomy is commonly performed before the extraction of common bile duct stones before or after laparoscopic cholecystectomy, ${ }^{3}$ although other techniques of stone removal without sphincterotomy are available for selected cases. ${ }^{4-8}$

In the 1970s, endoscopic sphincterotomy was considered justifiable only in elderly postcholecystectomy patients who were at high risk of serious complications from open surgical common bile duct exploration. As a result, long term complications of sphincterotomy were not a major concern because of the more advanced age of this group of patients. However, with improved efficacy, demand and training in therapeutic biliary endoscopic techniques, there has been an acceptable expansion of indications for endoscopic sphincterotomy and common bile duct stone removal, even in the average risk or younger patient with choledocholithiasis before or after laparoscopic cholecystectomy. The potential increase in the number of young patients undergoing sphincterotomy raises concerns about its complications in the short and long term in this group,,${ }^{10}$ together with possible higher risks of sphincterotomy in the young patient with nondilated ducts, ${ }^{11}$ especially when it is performed for sphincter of Oddi dysfunction. ${ }^{12}$

\section{Early complications of endoscopic sphincterotomy in young patients}

There have been few studies examining the incidence of sphincterotomy complications in young patients. Unlike surgery, where the risk increases with age and co-morbidity, the early complication rate of endoscopic sphincterotomy encountered in $8-10 \%$ of patients may not be related to age. ${ }^{13-15}$ The major complications include haemorrhage in $2-3 \%$, acute pancreatitis in $1-6 \%$, cholangitis in $1-3 \%$, and retroduodenal perforation in less than $1 \%{ }^{12}{ }^{16-22}$ Mortality from the procedure is reported as $0 \cdot 5-1 \% 1216-22$ with a 30 day mortality of $3-16 \%$ that is a reflection of the severity of underlying illness at the time of procedure. ${ }^{1822-26}$ These figures compare favourably with open surgery, in which the incidence of complications ranges from 10 to $46 \%$ with a mortality of $1.8 \%$ in patients under 50 years of age, increasing to $5-28 \%$ in patients over $60 . .^{1527}$

At present, endoscopic sphincterotomy is performed with increasingly frequency in patients with small bile ducts (less than $8 \mathrm{~mm}$ in diameter). There has been debate concerning a reported increased complication rate of $38 \%$ in patients with small diameter bile ducts, ${ }^{11}$ although the population reported was dominated by young patients with suspected sphincter of Oddi dysfunction. A large, multicentre, prospective study in the United States found that small bile duct diameter was a risk factor for pancreatitis only when endoscopic sphincterotomy was performed for sphincter of Oddi dysfunction, but not for other indications; haemorrhage was not influenced by age or small bile duct diameter. ${ }^{12} 16$ Another large, multicentre, prospective study, again in the United States, reported that the risk of sphincterotomy for stones in young patients with non-dilated ducts was very low $(4 \cdot 2 \%)$ in expert centres, ${ }^{17}$ and in young patients with dilated and non-dilated ducts, the overall early complication rate was only $6 \%$. Another series found an incidence of complications of $9.5 \%$ with no mortality. ${ }^{28}$ One group has presented a high complication rate of $14-27 \%$ with a mortality of $0.8 \%$ in young patients, although they were in relatively poor general medical condition and further details are not available. ${ }^{29}$

Thus, the limited data to date suggest that the short term risks of endoscopic sphincterotomy in the young, average risk patient are probably not significantly increased, even in those with non-dilated ducts, and may even be less.

\section{Theoretical long term risks of endoscopic sphincterotomy}

After endoscopic sphincterotomy, biliary reflux of duodenal chyme occurs in most patients, aerobilia is seen in half, and bacterobilia in all. ${ }^{30} 31$ Most patients with bacterobilia do not develop symptomatic cholangitis, but five $(20 \%)$ of 25 patients followed for a mean of 36 months experienced bouts of upper abdominal pain and associated increases in serum $\gamma$-glutamyltranspeptidase activities. ${ }^{32}$ In one study after endoscopic sphincterotomy $65 \%$ of patients had reflux from the duodenum into the biliary tree, detected by barium studies, ${ }^{33}$ although no clinical symptoms were observed in these patients in the absence of recurrent or retained stones. Another study found that $17 \%$ of patients with surgical transduodenal sphincterotomy had raised serum bilirubin and hepatic enzyme activities, possibly owing to reflux of chemical and bacterial 'irritants' into the biliary tree. ${ }^{34}$

Reflux of duodenal contents into the biliary tree after sphincterotomy is the consequence of reduction or abolition of sphincter of Oddi activity, as documented by manometry ${ }^{35}{ }^{36}$ even when performed 15 years following the sphincterotomy. ${ }^{36} \mathrm{Cetta}^{37}$ found that sphincterotomy 
(surgical and endoscopic) was associated with a fivefold greater incidence of postoperative bacterobilia and a sevenfold greater incidence of brown recurrent common duct stones compared with choledocholithotomy. Bacterobilia could be considered to be a factor in the formation of these stones as they are associated with infection with Escherichia coli, which probably results from contamination from the duodenum. ${ }^{37}$ Although such reflux may not always produce a clinical syndrome, the biochemical changes suggest that there may be some degree of continuing low grade damage within the liver parenchyma. Greenfield et $a l^{32}$ found that liver biopsy specimens of four of five patients who had raised aminotransferase activities and a previous sphincterotomy, showed periportal fibrosis and inflammation. Eleftheriadis $e t a l^{38}$ biopsied the bile duct mucosa one to 12 years after choledochoduodenostomy in nine asymptomatic patients and found in all patients hyperplasia of the epithelial cells, metaplastic goblet cells, pseudopyloric gland formation, dense inflammatory cell infiltration with lymphocytes, plasma cells and polymorphonuclear cells, and fibrosis. Similar findings were noted in an experimental study using sphincterotomy instead of choledochoduodenostomy. ${ }^{39}$ Thus, in theory, there is a risk of cholangitis, secondary bile duct changes and recurrent stone formation in the absence of any obstructive element after sphincterotomy. ${ }^{10}$

\section{Long term follow up after endoscopic sphincterotomy}

Although there are many reports of short term results and complications of endoscopic sphincterotomy, long term data are scarce and difficult to interpret. In addition, most reports have included patients of all ages and have not specifically looked at younger ones. Most of these studies are incomplete and the real incidence of complications may therefore be higher, or lower, if symptomatic patients are more likely to respond to inquiries and to accept endoscopic review. Periods of observation have also been relatively short.

The Table summarises the published data on long term follow up after endoscopic sphincterotomy. Hawes et $a l^{40}$ found that in $15(13 \%)$ patients with recurrent biliary problems, five had sphincter stenosis or stones, or both, which were treated endoscopically and three (two with cholangitis but no stones, one died with jaundice of uncertain cause) had not responded to endoscopic or conservative treatment. In the study by Riemann et $a l^{41}$ of 340 patients, 121 underwent endoscopy, revealing retained or recurrent stones in 23 and stenosis in three. As the symptoms of the patients agreeing to endoscopy are not stated, the true complication rate cannot be calculated, but presumably lies between $8 \%(26 / 340)$ and $21 \%(26 / 121)$.

Summary of published data on long term follow up (years) after endoscopic sphincterotomy

\begin{tabular}{|c|c|c|c|c|}
\hline Reference & & Patients (n) & $\begin{array}{l}\text { Follow up } \\
\text { (mean or range) }\end{array}$ & $\begin{array}{l}\text { Recurrent biliary } \\
\text { problems }(\%)\end{array}$ \\
\hline \multicolumn{5}{|l|}{ Includes patients of all ages: } \\
\hline Escourrou et al ${ }^{33}$ & & 96 & $0 \cdot 5-6$ & $5 \cdot 2$ \\
\hline Hawes et $a l^{40}$ & & 115 & $6-11$ & 13 \\
\hline Riemann et $a l^{41}$ & & 340 & $2-9$ & $8-21$ \\
\hline Ikeda et $a l^{42}$ & & 237 & $0.5-10.5$ & \\
\hline Clark et $a l^{43}$ & & 23 & 10 & 17 \\
\hline $\mathrm{Cetta}^{44}$ & & 55 & $3-10$ & $12 \cdot 7$ \\
\hline Safrany et $a l^{45}$ & & 588 & $? 2$ & 7 \\
\hline Rosch et $a^{46}$ & & 248 & $? 3$ & $12 \cdot 9$ \\
\hline Seifert et al ${ }^{47}$ & & 5437 & ?3 & 9 \\
\hline Jacobson and Matzen ${ }^{48}$ & & 52 & 4 & 8 \\
\hline Young patients: & Age & & & \\
\hline Tham et $a l^{28}$ & $<55$ & 30 & $0 \cdot 8-12$ & 10 \\
\hline Bergmann et al ${ }^{49}$ & $<60$ & 94 & $3-18$ & 24 \\
\hline Prat et al ${ }^{50}$ & $<70$ & 154 & $8-13$ & 10 \\
\hline
\end{tabular}

Ikeda $e t a l^{42}$ found that of the $11(4 \%)$ patients who had complications, four had died from recurrent biliary sepsis and seven of the survivors had biliary symptoms, of whom three had stones at endoscopy. Clark et al ${ }^{43}$ found that four $(17 \%)$ patients had recurrent or retained bile duct stones. In Cetta's study ${ }^{44}$ seven $(12 \cdot 7 \%)$ patients had major symptoms. Two had no evidence of stones, whereas five had brown recurrent common duct stones. The other studies published to date have had shorter follow up periods of up to seven years. ${ }^{33} 45-48$ Recurrent biliary problems were reported in 5-13\% of patients in these studies.

Only two studies to date have followed young patients after endoscopic sphincterotomy (Table). Bergman et al ${ }^{49}$ found that after a median of 15 years $22(24 \%)$ patients developed biliary complications, with recurrent bile duct stones being the most common problem. Of these, ERCP was performed in 20 patients and demonstrated bile duct stones in 13 combined with stenosis of the sphincterotomy in nine, which were managed endoscopically or conservatively, or both. One patient underwent surgery after failed endoscopic treatment and one patient died of cholangitis before she could undergo ERCP. One other patient had pancreatitis. Tham et $a l^{28}$ included patients who had both stones and sphincter of Oddi dysfunction followed up for a mean of eight years. They found that three $(10 \%)$ had further problems which included a pancreatic stricture from chronic pancreatitis, sphincter re-stenosis and cholangitis.

In a study of a slightly older group of patients under 70 years of age with a mean age of 55, Prat et $a l^{50}$ found that $16(10 \%)$ of 154 patients experienced biliary symptoms after a mean follow up of $9 \cdot 6$ years. Of these, nine $(5 \cdot 8 \%)$ developed potentially sphincterotomy related biliary symptoms such as papillary stenosis, recurrent common bile duct stones, hepatic abscesses, and cholangitis.

In summary, follow up studies of up to 18 years following endoscopic sphincterotomy have documented a $5-24 \%$ incidence of subsequent biliary complications such as recurrent stones, sphincter stenosis and cholangitis.

\section{Long term results of surgery}

Endoscopic results have to be compared with those of surgical exploration or re-exploration of the duct. The risk of long term complications with this procedure alone is substantial. From several studies, over a five to 10 year period, $14-36 \%$ of patients developed complications. ${ }^{51-56}$ However, if a drainage procedure was also performed, such as a choledochoduodenostomy or sphincteroplasty, the long term complications were less. After choledochoduodenostomy, over a three to 10 year period, the incidence of long term complications was described as $3-7 \% \%^{34} 515457$ and after sphincteroplasty over a four year period was 2-9\%. ${ }^{53} 57$ These series, however, are not strictly comparable with each other nor with endoscopic series as the spectrum of patients, definition of complications, methods, and completeness of follow up vary considerably. In addition, most surgical series report as complications only those patients who require another operation, which is most unusual after endoscopic sphincterotomy. In addition, from a theoretical perspective, a surgical drainage procedure may result in the same long term risks as endoscopic sphincterotomy. The long term results of endoscopic sphincterotomy therefore seem comparable with open surgery.

\section{Methods of removing bile duct stones without a sphincterotomy}

In an attempt preserve the sphincter of Oddi, other methods of removing bile duct stones have been described 
to avoid a sphincterotomy. Medical methods have been tried to relax the sphincter of Oddi using nitrates. In 21 patients, Staritz et al ${ }^{58}$ were able to remove small bile duct stones of 6-12 $\mathrm{mm}$ following dilation of the sphincter by glyceryl trinitrate administered sublingually with no complications. Follow up manometric examinations showed the papillary function to be well preserved. A Japanese group used intravenous infusion of isosorbide dinitrate and were able to extract small common bile duct stones (most $<10 \mathrm{~mm}$, maximum $16 \mathrm{~mm}$ in diameter) in $15(83 \%)$ of 18 patients. Pancreatitis occurred in one $(6 \%)$ patient who had unsuccessful stone extraction. ${ }^{8}$

In addition, attempts have also been made to remove small bile duct stones without having to perform any dilation of the sphincter, as reported in 15 patients with stones of a median diameter of $3 \mathrm{~mm} .{ }^{7}$ One $(7 \%)$ patient had mild pancreatitis after the procedure. Perhaps combination with other techniques - for example, mechanical lithotripsy to reduce the size of stones, may allow a wider range of patients to be managed without a sphincterotomy in the future, but such manipulations through the intact papilla are difficult.

Endoscopic balloon dilation of the sphincter before stone extraction has also been investigated. Staritz et $a l^{4}$ used balloon dilation of the papilla in 15 patients, 11 for common bile duct stones and four for papillary stenosis. They extracted all the stones with diameters of 6-12 mm with no complications. More recently, an Irish group ${ }^{5}$ attempted extraction of small stones with a mean size of $8 \mathrm{~mm}$ using this method in 28 patients, with success in 22 $(79 \%)$. Pancreatitis occurred in one $(4 \%)$ patient. In their recent update of 100 patients, they were successful in duct clearance in $82 \%$. Sphincterotomy was required to clear the duct in $7 \%$, and $6 \%$ of patients who were elderly with large stones had stents inserted plus ursodeoxycholic acid because of failure to clear the duct. Pancreatitis occurred in 5\%. Over a median 16 month follow up, $2 \%$ had recurrent symptomatic bile duct stones considered to have been unrecognised following the initial ERCP which were removed after repeat balloon dilation. ${ }^{6}$ In a prospective, randomised trial comparing endoscopic sphincterotomy with endoscopic balloon dilation, a group from Amsterdam reported that common bile duct stones with a median diameter of $10 \mathrm{~mm}$ could be extracted following balloon dilation in $90(89 \%)$ of 101 patients, with an incidence of complications in $17(19 \%)$ (one died from retroperitoneal perforation), which was comparable with endoscopic sphincterotomy, whereas mechanical lithotripsy was required more often in the balloon dilation group $(31 \% \quad v 14 \%) .{ }^{59}$ Cotton $^{60}$ successfully extracted small stones in seven young patients with normal sized ducts using balloon dilation of the sphincter, but it was not possible to calculate the incidence of complications from this report. Thus, balloon sphincter dilation seems to be a promising alternative to sphincterotomy in young patients with small stones in a normal sized duct. However, the question of long term sequelae remains unanswered. This method is currently being compared with sphincterotomy in ongoing randomised studies in the United States and Europe.

\section{Conclusions}

Endoscopic sphincterotomy seems to be a safe procedure for extracting common bile duct stones in young patients. The long term complications up to 18 years compare favourably with surgery, with up to $20 \%$ developing recurrent biliary problems which can be managed endoscopically. However, the very long term effects remain unknown and further studies in this area are required.
Currently, this procedure continues to be justified in young fit patients with bile duct stones who do not wish to undergo open surgery. In the future, methods of removing bile duct stones while preserving the sphincter, such as balloon dilation, may avoid some of the long term effects of sphincter ablation, but these might be replaced by other sequelae. The increasing use of laparoscopic methods of exploring the common bile duct during cholecystectomy will have the advantage of a one stage procedure for the patient but, in view of experience in the 'open' era, it seems unlikely that all surgeons will become expert in such techniques.

Division of Medicine, Ulster Hospital, Dundonald,

T C K THAM Belfast BT16 0RH, Northern Ireland

D L CARR-LOCKE Division of Gastroenterology, Brigham and Women's Hospital, Harvard Medical School, Boston, MA, USA

\section{J S A COLLINS}

Royal Victoria Hospital, Belfast, Northern Ireland

Correspondence to: Dr T C K Tham.

1 Van der Hul RL, Plaisier PW, HammingJF, Bruining HA, Van Blankenstein M. Detection and management of common bile duct stones in the era of laparoscopic cholecystectomy. Scand f Gastroenterol 1993; 28: 929-33.

2 Scott-Coombes D, Thompson JN. Bile duct stones and laparoscopic cholecystectomy. BMf 1991; 303: 1281-2.

3 Boulay J, Schellenberg R, Brady PG. Role of ERCP and therapeutic biliary endoscopy in association with laparoscopic cholecystectomy. $\mathrm{Am} F$ Gastroenterol 1992; 87: 837-42.

4 Staritz M, Ewe K, Meyer zum Buschenfelde KH. Endoscopic papillary dilatation (EPD) for the treatment of common bile duct stones and papillary stenosis. Endoscopy 1983; 15: 197-8.

5 MacMathuna P, White P, Clarke E, Lennon J, Crowe J. Endoscopic sphincteroplasty: a novel and safe alternative to papillotomy in the sphincteroplasty: a novel and safe alternative to papi

6 MacMathuna P, White P, Clarke E, Merriman R, Lennon JR, Crowe J. Endoscopic balloon sphincteroplasty (papillary dilation) for bile duct stones: efficacy, safety and follow-up in 100 patients. Gastrointest Endosc 1995; 42: 468-74.

7 May GR, Cotton PB, Edmunds SE, Chong W. Removal of stones from the bile duct at ERCP without sphincterotomy. Gastrointest Endosc 1993, 39: $749-54$.

8 Ibuki Y, Kudo M, Todo A. Endoscopic retrograde extraction of common bile duct stones with drip infusion of isosorbide dinitrate. Gastrointest Endosc 1992; 38: 178-80.

9 Shields SJ, Carr-Locke DL. Sphincterotomy techniques and risks. Gastrointest Endosc Clin North Am (in press)

10 Johnston GW. Iatrogenic chymobilia - a disease of the nineties? HPB Surg 1991; 4: 187-90.

11 Sherman S, Ruffolo TA, Rawes RH, Lehman GA. Complications of endoscopic sphincterotomy. A prospective series with emphasis on the increased risk associated with sphincter of Oddi dysfunction and nondilated bile ducts. Gastroenterology 1991; 101: 1068-75.

12 Freeman $M$, Nelson D, Sherman $S$, and the MESH study group. Pancreatitis from endoscopic sphincterotomy (ES): A prospective, multicenter, 30-day study [abstract]. Gastrointest Endosc 1994; 40: P108.

13 Neoptolemos JP, Shaw DE, Carr-Locke DL. A multivariate analysis of preoperative risk factors in patients with common bile duct stones. Implications for treatment. Ann Surg 1989; 209: 157-61.

14 Cotton PB. Endoscopic management of bile duct stones: (apples and oranges). Gut 1984; 25: 587-97.

15 Saraswat VA, Tandon RK. Duodenoscopic sphincterotomy for biliary calculi. 7 Gastroenterol Hepatol 1990; 5: 686-96.

16 Freeman $M$, Nelson $D$, Sherman $S$, and the MESH study group. Hemorrhage from endoscopic sphincterotomy (ES): A prospective, multicenter, 30-day study [abstract]. Gastrointest Endosc 1994; 40: P108.

17 Cotton PB, Geenen J, Sherman S, et al. Sphincterotomy for stone is safer than advertised, even in young patients with small ducts. A multicenter prospective study [abstract]. Gastrointest Endosc 1994; 40: P104

18 Leese T, Neoptolemos JP, Carr-Locke DL. Successes, failures, early complications and their management following endoscopic sphincterotomy: results in 394 consecutive patients from a single centre. Br f Surg 1985; 72: 215-9.

19 Safrany L. Endoscopic treatment of biliary tract diseases. Lancet 1978; ii: 983-5.

20 Cotton PB, Vallon AG. British experience with duodenoscopic sphincterotomy for removal of bile duct stones. Br $\mathcal{F}$ Surg 1981 ; 68: 373-5.

21 Lambert ME, Betts CD, Hill J, Faragher EB, Martin DF, Tweedle DEF Endoscopic sphincterotomy: the whole thruth. Br $\mathcal{f}$ Surg 1991; 78: $473-6$

22 Vaira D, Ainley C, Williams S, et al. Endoscopic sphincterotomy in 1000 consecutive patients. Lancet 1989; ii: 431-3.

$23 \mathrm{Siegel} \mathrm{JH}$. Endoscopic papillotomy in the treatment of biliary tract disease: 258 procedures and results. Dig Dis $S_{c i} 1981 ; 68: 373-5$.

24 Lewis FW, Moloo N, Stiegmann GV, Goff JS. Splenic injury complicating therapeutic upper gastrointestinal endoscopy and ERCP. Gastrointest Endosc 1991; 37: 632-3.

25 Stone HH, Fabian TC, Dunlop WE. Gallstone pancreatitis. Biliary tract pathology in relation to time of operation. Ann Surg 1981; 194: 305-12.

26 Acosta JM, Rossi R, Galli OMR, Pellegrini CA, Skinner DB. Early surgery for acute gallstone pancreatitis: Evaluation of a systematic approach Surgery $1978 ; 83$ : $367-70$. 
27 Peel ALG. The challenge of the bile duct in 1990. Ann $R$ Coll Surg Engl 1990; 72: 165-7.

28 Tham TCK, Kennedy R, O'Connor FA. Early complications and mean 8 year follow-up after endoscopic sphincterotomy in young fit patients. Eur (

29 Maxton DG, Tweedle DEF, Martin DF. Endoscopic sphincterotomy in the younger patient: Success and complications [abstract]. Gut 1993; 34 (suppl): \$48.

30 Seifert E. Long term follow up after endoscopic sphincterotomy (EST) Endoscopy 1988; 20: 232-5.

31 Gregg JA, Girolami PD, Carr-Locke DL. Effects of sphincteroplasty and ensocopic sphincterotomy on the bacteriologic characteristics of the common bile duct. $A m \mathcal{F}$ Surg 1985; 149: 668-71.

32 Greenfield C, Cleland P, Dick R, Masters S, Summerfield JA, Sherlock S. Biliary sequelae of endoscopic sphincterotomy. Postgrad Med $\mathcal{F} 1985 ; 61$ : 213-5.

33 Escourrou J, Cordova A, Lazorthes F, Frexinos J, Ribet A. Early and late complications after endoscopic sphincterotomy for biliary lithiasis with and without the gallbladder in situ. Gut 1984; 25: 598-602

34 Baker AR, Neoptolemos JP, Leese T, James DC, Fossard DP. Long term follow-up of patients with side to side choledochoduodenostomy an transduodenal sphincterotomy. Ann R Coll Surg Engl 1987; 69: 253-8.

35 Gregg JA, Carr-Locke DL. Endoscopic pancreatic and biliary manometry in pancreatic, biliary and papillary disease, and after endoscopic sphincterotomy and surgical sphincteroplasty. Gut 1984; 25: 1247-54.

36 Bergman JJGHM, van Berkel AM, Groen AK, et al. Is the function of the biliary sphincter permanently lost after endoscopic sphincterotomy (EST)? Manometric findings and bacterial characteristics 15 years after EST [abstract]. Gastroenterology 1995; 108: A406.

37 Cetta F. Do surgical and endoscopic sphincterotomy prevent or facilitate recurrent common duct stone formation? Arch Surg 1993;128: 329-36.

38 Eleftheriadis E, Tzioufa V, Kotzampassi K, Aletras H. Common bile duct mucosa in choledochoduodenostomy patients - histological and histochemical study. HPB Surg 1988;1: 15-20.

39 Fihlo ES. Histological alterations of the liver, gallbladder and common bile duct after papillotomy [abstract]. Dig Dis Sci 1986; 31: 379S.

40 Hawes RH, Cotton PB, Vallon AG. Follow-up 6 to 11 years after duodenoscopic sphincterotomy for stones in patients with prio cholecystectomy. Gastroenterology 1990; 98: 1008-12.

41 Riemann JR, Lux G, Forster P. Long-term results after endoscopic papillotomy. Endoscopy 1981; 13: 152 .

42 Ikeda S, Tanaka $M$, Matsumoto S, Yoshimoto H, Itoh H. Endoscopic sphincterotomy: long-term results in 408 patients with complete followup. Endoscopy 1988; 20: 13-17.

43 Clark DW, Geenen JE, Hogan WJ, Johnson GK, Schmalz MJ, Catalano MF. Ten year follow-up of patients undergoing endoscopic sphincterotomy for common bile duct stones [abstract]. Gastrointest Endosc 1994; 40: P104.
44 Cetta FM. The role of bacteria in pigment gallstone disease. Ann Surg 1991; 213: 315-26.

45 Safrany L, Schott B, Balint T. Endoscopic sphincterotomy: the long term results in choledocholithiasis. Gastrointest Endosc 1982; 28: 152.

46 Rosch W, Riemann JR, Lux G, Linder HG. Long-term follow-up after endoscopic papillotomy. Endoscopy 1981; 13: 152.

47 Seifert E, Gail K, Weismuller J. Langzeitresultate nach endoskopischer sphinkterotomie: follow-up studie aus 25 Zentren in der Bundesrepublik. Dtsch Med Wochenschr 1982; 107: 610 .

48 Jacobson O, Matzen P. Long-term followup of patients after endoscopic sphincterotomy for choledocholithiasis. Scand $\mathcal{F}$ Gastroenterol 1987; 22. 903-6.

49 Bergman IIGHM, van der Mey S, Rauws EAJ, Tytgat GNJ, Huibregste K. Late complications after endoscopic sphincterotomy for bile duct stones in patients younger than 60 years. Gastrointest Endosc 1995; 41: 389.

50 Prat F, Abdel Malak N, Pelletier G, et al. Biliary symptoms and complications more than 8 years after endoscopic sphincterotomy for cations more than 8 years after endoscopic sp

51 Lygidakis NJ. Surgical approaches to recurrent choledocholithiasis choledochoduodenostomy versus $\mathrm{T}$-tube drainage after choledochotomy Am $\mathcal{F}$ Surg 1983; 145; 636-9.

52 Larson RE, Hodgson JR, Priestley JT. The early and long term results of 500 consecutive explorations of the common duct. Surg Gynecol Obste 1966; 122: 44-750.

53 Peel ALG, Bourke JB, Hermon-Taylor J, MacLean ADW, Mann CV, Ritchie HD. How should the common bile duct be explored? Ann R Coll Surg Engl 1975; 56: 124-34.

54 Allen B, Shapiro H, Way L. Management of recurrent and residual common duct stones. Am $\mathcal{F}$ Surg 1981; 142: 41-7.

55 Saharia PC, Zuidema G, Cameron JL. Primary common duct stones. Ann Surg 1977; 185: 598-604.

56 Braasch JW, Fender HR, Bonneval MM. Refractory primary common bile and duct stone disease. Am 7 Surg 1980; 139: 526-30.

57 Thomas CG, Nicholson CP, Owen J. The effectiveness of choledochoduodenostomy in the treatment of benign obstruction of the common duct. Ann Surg 1971; 173: 845-6.

58 Staritz M, Poralla T, Dormeyer HH, Meyer zum Buschenfelde $\mathrm{KH}$ Endoscopic removal of common bile duct stones through the intact papilla after medical sphincter dilation. Gastroenterology 1985; 88. $1807-11$

59 Bergman JJGHM, Rauws EAJ, Fockens P, van Berkel AM, Bossuyt PMM, Tyssen JCP, et al. Randomised trial of endoscopic balloon dilation versus endoscopic sphincterotomy for removal of bile duct stones. Lancet 1997; 349: 1124-9.

60 Cotton PB. Removing duct stones without sphincterotomy. Gastrointest Endosc 1993; 39: 313 . 